\title{
A clinical study of large ovarian cyst with various presentations: prospective interventional study
}

\author{
Yellapragada Lakshmi Nalini ${ }^{1}$, Deepak Sharma ${ }^{2 *}$, \\ A. Sarath Chandra ${ }^{2}$, B. S. Lakshmi Deepshika ${ }^{2}$
}

\begin{abstract}
${ }^{1}$ Department of Obstetrics and Gynecology, ${ }^{2}$ Department of Surgery, Malla Reddy Institute of Medical Sciences, Hyderabad, Telangana, India
\end{abstract}

Received: 08 November 2017

Accepted: 02 December 2017

*Correspondence:

Dr. Deepak Sharma,

E-mail: sharma.deepakdr@gmail.com

Copyright: () the author(s), publisher and licensee Medip Academy. This is an open-access article distributed under the terms of the Creative Commons Attribution Non-Commercial License, which permits unrestricted non-commercial use, distribution, and reproduction in any medium, provided the original work is properly cited.

\begin{abstract}
Background: The definition of huge ovarian cysts is not well described in the literature. Some authors define large ovarian cysts as those that are more than $10 \mathrm{~cm}$ in diameter as measured by preoperative scans. An ovarian cyst is a common gynecological problem and is divided into two main categories; physiological and pathological. Aims and objectives of this study was to find out various presentations of large ovarian tumour.

Methods: It was a prospective interventional study done for a period of two year from March 2015 to March 2017 in Department of Obstetrics and Gynecology as well as in Department of General Surgery. During the study period a total of 30 study participants were enrolled.

Results: Majority of the study participants were in the age group of $18-28$ years $(66.66 \%)$ and $33.33 \%$ were in the age group of 28-38 years. Near about 33.33\% were uncomplicated. Near about $33.33 \%$ presented with tortion, $7 \%$ with rupture of cyst, infection was seen in $13.33 \%$. About $13.33 \%$ were malignant cyst.

Conclusions: Large ovarian cysts are a clinical challenge for Gynaecologists. Quite a good number of these cases can end up with complications and hence, all of them have to be subjected to surgery.
\end{abstract}

Keywords: Cyst, Laparotomy, Ovarian, Tumour

\section{INTRODUCTION}

An ovarian cyst is a common gynecological problem and is divided into two main categories; physiological and pathological. ${ }^{1}$ Physiological cysts are follicular cysts and luteal cysts. Pathological cysts are considered as ovarian tumors, which might be benign, malignant, and borderline. Benign tumors are more common in young females, but malignant are more frequent in elderly females. ${ }^{2}$ When ovarian cysts are large, they may cause abdominal discomfort. If pressing on the bladder it may also cause frequency of urination. ${ }^{3}$ The signs and symptoms of ovarian cysts may include; pelvic pain, dysmenorrheal, and dyspareunia. Other symptoms are nausea, vomiting, or breast tenderness, fullness and heaviness in the abdomen and frequency and difficulty emptying of the bladder. ${ }^{4}$

The definition of huge ovarian cysts is not well described in the literature. Some authors define large ovarian cysts as those that are more than $10 \mathrm{~cm}$ in diameter as measured by preoperative scans. ${ }^{5}$ Others define large ovarian cysts as those that are reaching above the umbilicus. ${ }^{6}$ Laparoscopic management of huge ovarian cysts has been described in previous case reports. ${ }^{7-9}$ Despite this, most patients with huge ovarian cysts are managed by laparotomy. Therefore, the present study was conducted with the objectives to find out various 
presentations of large ovarian tumour and to intervene surgery depending upon the presentation.

\section{METHODS}

This was A hospital based prospective interventional study carried out in Department of Obstetrics and Gynecology and Department of General Surgery at Malla Reddy Institute of Medical Sciences, Hyderabad.

Study population consisted of all women who came to Obstetrics and Gynaecology Department with a history of abdominal lump who were rule out as ovarian cyst on examination as well as on USG.

The study was done for a period of two years from March 2015-March 2017. A total of 30 study participants were enrolled in the study.

\section{Methodology}

Study participants who came with a history of abdominal lump and who were ruled out on clinical as well as USG findings as ovarian cyst were included in the study. A detailed history was taken considering variables as Age, duration of lump, complication due to lump. A detailed clinical examination was done and certain investigations such as USG abdomen, Doppler study, histopathological examination of lump etc. were done. The study participants underwent surgical intervention depending upon the USG and histopathological report. All the operated study participants were followed up for a period of two years to see any recurrence.

\section{Statistical analysis}

Data was entered in Microsoft excel sheet and analyzed using simple proportions.

Institutional ethics committee permission of MRIMS was obtained before the start of the study. Informed and written consent was obtained from every participant.

\section{RESULTS}

Table 1 shows majority of the study participants were in the age group of $18-28$ years $(66.66 \%)$ and $33.33 \%$ were in the age group of 28-38 years respectively.

Table 1: Distribution of study participants according to age.

\begin{tabular}{|lll|}
\hline Age (years) & Frequency & Percentage \\
\hline $18-28$ & 20 & 66.66 \\
\hline $28-38$ & 10 & 33.33 \\
\hline Total & 30 & 100 \\
\hline
\end{tabular}

Table 2 shows near about $66.66 \%$ were having cyst size of $10-20 \mathrm{~cm}$ and $33.33 \%$ were having cyst size of $20-34$ $\mathrm{cm}$.
Table 2: Distribution of study participants according to size of cyst.

\begin{tabular}{|lll|}
\hline Size $(\mathrm{cm})$ & Frequency & Percentage \\
\hline $10-20$ & 20 & 66.66 \\
\hline $20-34$ & 10 & 33.33 \\
\hline Total & 30 & 100 \\
\hline
\end{tabular}

Table 3 shows about $33.33 \%$ were uncomplicated. Near about $33.33 \%$ presented with tortion, $7 \%$ with rupture of cyst, infection was seen in $13.33 \%$. About $13.33 \%$ were malignant cyst.

Table 3: Distribution of study participants with complication of cyst.

\begin{tabular}{|lll|}
\hline Complications & Frequency & Percentage \\
\hline Torsion & 10 & 33.33 \\
\hline Rupture & 2 & 6.66 \\
\hline Infection & 4 & 13.33 \\
\hline Malignancy & 4 & 13.33 \\
\hline Uncomplicated & 10 & 33.33 \\
\hline Total & 30 & 100 \\
\hline
\end{tabular}

Table 4 shows among all study participants USG abdomen was done. In $33.33 \%$ of the study participants CT abdomen was done. CA 125 was done in all cases and values of $>35$ were seen in 4 cases. LDH was increased in one of the cases with histopathology proving germ cell tumor. Inhibin was raised in 1 case where histopathology was granulosa cell tumor. CEA was raised in 1 case of mucinous cystadenoma. 19 cases were serous cystadenomas. Mucinous cystadenomas were noted in 3 cases in which 1 was carcinoma.

Table 4: Different diagnostic tools used.

\begin{tabular}{|lll|}
\hline Diagnostic tool & Frequency & Percentage \\
\hline Ultrasound abdomen & 30 & 100 \\
\hline CT scan & 10 & 33.33 \\
\hline Ca-125 $>35$ & 4 & 13.33 \\
\hline Ca-125 $<35$ & 26 & 86.66 \\
\hline LDH & 1 & 3.33 \\
\hline Inhibin & 1 & 3.33 \\
\hline CEA & 1 & 3.33 \\
\hline
\end{tabular}

Table 5 shows near about $93.33 \%$ had unilocular thin cyst and $7 \%$ were unilocular solid cyst.

Table 5: Type of cyst on ultrasonography abdomen.

\begin{tabular}{|lll|}
\hline Type of cyst & Frequency & Percentage \\
\hline Unilocular thin cyst & 28 & 93.33 \\
\hline Unilocular Solid cyst & 2 & 6.6 \\
\hline Total & 30 & 100 \\
\hline
\end{tabular}

All cases were subjected to laparotomy and cystectomy was the preferred surgery. 2 of our cases have undergone additional hysterectomy (suspected malignancy). 1 
malignant case was unmarried, and the disease was in Stage I, hence only cystectomy was done. All cases were subjected to chemotherapy. Follow up was done for period of 2 years at 6-month interval to see for recurrence. No recurrence of cyst was observed.

\section{DISCUSSION}

In present study majority of the study participants were in the age group of $18-28$ years $(66.66 \%)$ and $33.33 \%$ were in the age group of 28-38years respectively. The present study findings were consistent with other study done by Patrick et al where $41 \%$ of the study participants were in the age group of 21-30years. ${ }^{10}$

Among all study participants USG abdomen was done in present study. In $33.33 \%$ of the study participants CT abdomen was done. CA 125 was done in all cases and values of $>35$ were seen in 4 cases. $\mathrm{LDH}$ was increased in one of the cases with histopathology proving germ cell tumor. Inhibin was raised in 1 case where histopathology was granulosa cell tumor. CEA was raised in 1 case of mucinous cystadenoma. $63.33 \%$ cases were serous cystadenomas were as in another study $20 \%$ were serous cystadenomas. ${ }^{11}$ In another study serous cyst adenomas were $11 \%$ and mucinous were $8 \%$ respectively. ${ }^{10}$ Near about $10 \%$ were mucinous cystadenoma and in another study 5\% were mucinous cystadenoma. In present study $3.33 \%$ was malignancy found while in another study $11 \%$ of the ovarian cyst were malignant. ${ }^{11}$

All cases were subjected to laparotomy and cystectomy was the preferred surgery. Two cases have undergone additional hysterectomy (suspected malignancy). Among all cases one malignant case was unmarried and the disease was in Stage I, hence only cystectomy was done. In another study $18.7 \%$ cases underwent cystectomy and $3 \%$ underwent laparoscopy followed by laprotomy. ${ }^{12}$ In another study they quoted that the definitive management for large ovarian cyst is laparotomy and excision of the cyst, but authors have also quoted that huge ovarian cysts can be managed by laparoscopic means.

In the event of complicated large ovarian cysts like rupture, torsion, hemorrhage, malignancy and infection, laparotomy is the procedure of choice, along with excision of the cyst. Patients with large ovarian cysts along with pregnancy should be subjected to laparotomy, caesarean section and cystectomy. If surgery is required it is advantageous to perform it in the early second trimester, as the risk of abortion is lower at that time. ${ }^{13}$

\section{CONCLUSION}

Large ovarian cysts are a clinical challenge for Gynaecologists. Quite a good number of these cases can end up with complications and hence, all of them have to be subjected to surgery. Malignant ovarian cysts must be followed up with chemotherapy.

Funding: No funding sources

Conflict of interest: None declared

Ethical approval: The study was approved by the Institutional Ethics Committee

\section{REFERENCES}

1. Grimes DA, Jones LB, Lopez LM, Schulz KF. Oral contraceptives for functional ovarian cysts. Cochrane Database Syst Rev. 2014;4:CD006134.

2. Hongqian L, Xiangao W, Donghao L, Zhihong L. Gang S. Ovarian masses in children and adolescents in China: analysis of 203 cases. J Ovarian Res. 2013;6:47.

3. Rofe G, Auslend R, Dirnfeld M. Benign ovarian cysts in reproductive-age women undergoing assisted reproductive technology treatment. Open J Obstet Gynecol. 2013;3:17-22.

4. Farghaly SA. Current diagnosis and management of ovarian cysts. Clin Exp Obstet Gynecol. 2014;41:60912.

5. Ou CS, Liu YH, Zabriskie V, Rowbotham R, Alternate methods for laparoscopic management of adnexal masses greater than $10 \mathrm{~cm}$ in diameter. J Laparoendoscopic Advanced Surgical Techniques. 2001;11(3):125-32.

6. Salem HA. Laparoscopic excision of large ovarian cysts. J Obstet Gynaecol Res. 2002;28:290-4.

7. Nagele F, Magos AL. Combined ultrasonographical guided drainage and laparoscopic excision of a large ovarian cyst. Am J Obstet Gynecol. 1996;175(5):13778.

8. Jeong EH, Kim HS, Ahn CS. Successful laparoscopic removal of huge ovarian cysts. J Am Assoc Gynecol Laparoscopists. 1997;4:609-14.

9. Postma VA, Wegdam JA, Janssen IM. Laparoscopic extirpation of a giant ovarian cyst. Surg Endoscopy. 2002;16(2):361.

10. Patrick UE, Lucky KE. Benign ovarian tumours in a tertiary care hospital in Niger delta, Nigeria: a 10 year histopathological study. Int J Cur Res Rev. 2015;7(8).

11. Chanu SM, Dey B, Raphael V, Panda S, Khonglah Y. Clinico-pathological profile of ovarian cysts in a tertiary care hospital. Int J Reprod Contracept Obstet Gynecol. 2017;6(10):4642-5.

12. Beeresh CS, Doopadapalli D, Vimala KV, Lingegowda K. Laparoscopic management of large ovarian cysts. Int J Reprod Contracept Obstet Gynecol. 2017;6(5):19992002.

13. Eltabbakh G. Laparoscopic surgery for large ovarian cysts: review. Trends Gynecol Oncol. 2016;2:109.

Cite this article as: Nalini YL, Sharma D, Chandra AS, Deepshika BSL. A clinical study of large ovarian cyst with various presentations: prospective interventional study. Int J Reprod Contracept Obstet Gynecol 2018;7:239-41. 